ISSN 2080-1653

DOI 10.24917/20801653.324.10

JOANNA DOMINIAK

Adam Mickiewicz University, Poznań, Poland

\title{
Contemporary Issues of Services in Light of Polish Geographic Literature
}

\begin{abstract}
Service activity, which is an essential part of modern economy, is constantly changing. The changing economic reality also involves changes in research orientations. Changes in the subject of interest in the literature related to geography of services are a reflection of the changes taking place in services. Economic changes, as well as technological and civilisation progress, result in the emergence of new directions of research, as well as the disappearance of some of the existing ones, which in current circumstances are losing their relevance. The beginnings of geography of services as a distinctive scientific discipline date back to the 1970s. Previously, service research was part of the field of settlement research. The 1970s brought an increased interest in services, which initiated the process of crystallising geography of services, manifested in both theoretical and methodological work. The article discusses current changes in Polish geography of services, in particular its new trends and research directions.
\end{abstract}

Keywords: geography of services; literature review; Poland

Received: 10 May 2018

Accepted: 2 August 2018

Suggested citation:

Dominiak, J. (2018). Contemporary Issues of Services in Light of Polish Geographic Literature. Prace Komisji Geografii Przemysłu Polskiego Towarzystwa Geograficznego [Studies of the Industrial Geography Commission of the Polish Geographical Society], 32(4), 163-175. https://doi.org/10.24917/20801653.324.10

\section{INTRODUCTION}

Service activity, which is an essential part of modern economy, is constantly changing. The changing economic reality also involves changes in research orientations. Transformations of economy with technological and civilisation progress result in the emergence of new directions and trends of research, as well as the disappearance of some of the existing ones, which under current conditions cease to be relevant and lose their significance. It is a natural development process of any scientific discipline. "Scientific progress, responding to current questions, leads to civilisation development, and this in turn opens new research fields through the emergence of new research needs" (Retkiewicz, 2014a: 157). Similar trends are observed in the area of geography of services. It 
is connected with the basic role of geography, which according to Z. Chojnicki (1991: 371-372) is to "more faithfully and deeply describe and understand the world, and thus obtain a more interesting and useful knowledge".

The beginnings of independent systematic research on geography of services as a distinctive scientific discipline date back to the 1970s (Werwicki, 1998; Kłosowski, 2006a; 2006b; Ilnicki, 2014). In the past, research on services was mainly conducted within the field of settlement research. Only the 1970s brought increased interest in geography of services, and its crystallisation into a separate discipline, manifested in publishing both theoretical and methodological papers (Polarczyk, 1970, 1971, 1976a, 1976b; 1979, Nowosielska, 1994). Since then, there has been a continuous increase in the number of research papers related to services. D. Ilnicki (2014) notes, however, that Polish literature on the subject lacks comprehensive, synthetic studies that capture the problems of the sector and the entire sphere of services. Nowadays, studies on services are fragmentary, both in relation to the composition of services and the scale of analysis (Ilnicki, 2014). This brings, among others, a lack of visual progress on the basis of theory, practice and methodology of geography of services. The reasons for this state of affairs is believed to be primarily in the heterogeneity of services and conditions related to the lack of interest by stakeholders positioned in economy and politics (Jakubowicz, 1993; Nowosielska, 1994; Ilnicki, 2014).

In the development of Polish research on services, D. Ilnicki (2009) proposes the delimitation of four periods: (1) the beginning of research on services - until the early 1970s, (2) systematic service surveys (1970s and 1980s), (3) the first decade of the transformation period (1990s), and (4) contemporary geography of services (from the turn of the century). A comprehensive chronological and thematic approach to services in Polish literature on the subject was presented by D. Ilnicki $(2009,2014)$. The aim of this article is to try to discuss the contemporary changes in Polish geography of services, in particular the characteristics of new trends and research directions, attempt to answer the question in which direction it is developing and what its challenges and possible scenarios for further development are. The time range of this analysis is the last period of development of Polish geography of services, which dates back to the beginning of the 2000s.

\section{CHARACTERISTICS OF CONTEMPORARY RESEARCH TRENDS IN POLISH GEOGRAPHY OF SERVICES}

As mentioned in the introduction, service activity, which is an essential part of modern economy, is subject to constant changes, which is reflected in the achievements of geography of services. The transformations taking place in the sphere of services can be considered through structural and restructuring changes. A similar division can be applied to the main contemporary research trends. In structural terms, the achievements of contemporary Polish geography of services include, among others: (1) increased interest in modern services based on knowledge; (2) undiminished dominance of studies in the field of broadly understood commercial services, (3) relatively weaker achievements in the field of public services. In addition to structural changes in the sphere of services, there are also organisational changes, which are also reflected in the achievements of modern geography of services. Among them, the most important are: (1) outsourcing of services resulting from the increase in competitiveness linked to 
the globalisation process; ( 2 ) the process of internationalisation of services as a result of progressive globalisation (the phenomenon of offshoring); (3) changes in terms of forms of distribution and the provision of services, and contact with the customer as a result of technological progress, in particular the development of the ICT sector. In the further part of the study, an attempt was made to organise the achievements of contemporary Polish geography of services in reference to the presented transformations in the sphere of services.

One of the basic features of the achievements of Polish geography of service is its fragmentary and an increasing number of detailed studies related to the narrow scope of certain types of services. The increase in interest in modern knowledge-based services (knowledge-intensive) is particularly visible. According to theories of service activity, knowledge-intensive services are gaining importance in the structure of modern economy. Their development was caused, inter alia, by increased competitiveness and the related increase in the demand for specialised and modern services using advanced technologies, both within the enterprise and acquired. They play an important role at every stage of the development of innovative economy (from generation of innovation, through its transfer to economic practice, support of the commercialisation process, to sales) and thus are becoming its indispensable element. The growing importance of this type of services in the economy is also reflected in the number of studies on this subject. Among the works in this field, one can list studies on the diversification of the level of development of services based on knowledge (Knowledge Intensive Services - KIS), or their part related to business support (Knowledge Intensive Business Services - KIBS), and the role they play in dynamising the processes of economy based on knowledge (KBE) in various spatial scales: in the EU countries (Skórska 2012, 2015; Węgrzyn, 2013; Zięba, 2015; Wyszkowsa-Kuna, 2016), and in regional terms (Skórska, 2016; Dominiak, 2017a). In this context, in the subject literature, there is also the concept of new and modern services (largely identified with more or less services based on knowledge). In Polish literature, the term new services was used, among others, in the following studies: E. Jakubowicz (2000), M. Sobczyński, A. Słowik (2000), A. Janc (2001), D. Ilnicki (2001; 2003; 2009), J. Dominiak (2017a). New services include dynamically developing services with high knowledge saturation, related to IT support, scientific, research and development, financial, insurance and broadly understood consulting services (organisational, economic, technical, marketing, etc.) (Dominiak, 2017a, 2017b). These services have developed in Poland only after the systemic changes of 1989 , and their importance in the development of innovative and competitive economy is constantly growing, which is reflected in the increase in interest in this type of services in publications. The achievements related to spatial diversification of the development of specific types of knowledge-intensive services are dominated by the studies related to: (1) ICT services (e.g. Męczyński, 2006; Micek, 2006, 2008; Stryjakiewicz, 2009; Strożek, Jewczak, 2016), (2) financial services (e.g. Ilnicki, 2003; 2006; 2007; 2008; Weltrowska, 2003; 2007; Brezdeń, Spallek, 2009), and (3) services for producers and business (e.g. Dominiak, 2006, 2008a, 2008b, 2012b, 2013, 2018; Dzieciuchowicz, 2009a, 2009b, 2009c, 2009d, 2009e, 2009f).

In addition to the dynamic increase in the number of studies related to knowledge-based services, the continuation of a large interest in traditional services, including primarily commercial ones, can be noted in the output of modern geography of services. Geography of trade, dealing with the study of trade in space, including most of 
all the links between the distribution of enterprises and commercial establishments versus consumer behaviour, is one of the basic areas of geography of services (Dzieciuchowicz, 2012a). According to J. Dzieciuchowicz (2012a), traditionally the most important research topics of geography of trade include: (1) analysis of market areas of outlets and service centres; (2) determinants and models of spatial behaviour of store customers; (3) spatial and institutional organisation of trade; (4) internationalisation of wholesale and retail trade; and (5) impact of technological progress on the development and distribution of trade. The evolution of the problems of geography of trade in Poland is presented in the studies of, among others, D. Ilnicki (2009), S. Ciok and D. Ilnicki (2011), and J. Dzieciuchowicz (2012a). They draw attention to the emerging new directions related to the creation, evolution, location of new shopping centres in urban space and urban agglomeration as multifunctional outlets combining commercial, gastronomic, cultural and recreational functions (Kaczmarek, Kaczmarek, 2006; Kaczmarek, 2014; Więcław-Michniewska, 2006) and retail chains (Wilk, 2005, 2012, 2013). J. Dzieciuchowicz (2012a) writes about new geography of trade that begun in the 1990s in which most attention is paid to contemporary changes in trade in the socio-economic space. Among the key research problems dealt with by new geography of trade J. Dzieciuchowicz (2012a) lists the following: concentration and restructuring of trade in space, trade supply networks, areas of trade exclusion, geography of international trade and geography of virtual trade.

Public services are much less popular in geographical surveys. In this area, we find studies primarily related to geography of education, devoted to higher education, focusing on academic centres and analysing their impact on the development of cities and regions (e.g. Gaczek, 2006; Wolaniuk, 2006, 2008; Bajerski, 2008; Wiśniewski, 2008; Ilnicki, 2008).

In addition to structural changes in the sphere of services, there are organisational changes too, which are also reflected in the achievements of modern geography of services. An important role in these changes in services is played by the globalisation process. Between the two megatrends - the process of service development (servicisation) and the globalisation process, there are bilateral relationships that dynamise both processes (Naisbitt, 1997; Masłowski, 2008). On the one hand, globalisation stimulates the demand for new services, on the other - the rapid development of services, especially the ICT sector, favours the processes of globalisation. The ongoing globalisation along with the increase in competitiveness is the direct cause of significant organisational changes in service activities. These include: the process of internationalisation of services, externalisation of service provision and the use of outsourcing in order to minimise the operating costs of enterprises. Many studies related to the service sector are devoted to the issues of changes in the processes of organisation of service activities in the era of globalisation. First of all, they mainly concern the outsourcing and offshoring processes. Relocation of services following globalisation is the subject of studies of, for instance, A. Zorska $(2007,2008)$ and B. Liberska (2008). The increase of interest in the literature of subject in the centres of shared services, which provide services (usually IT, accounting, etc.) to the units of a given international corporation worldwide, is particularly noticeable. Poland sees its chance of development as a country with well-educated staff and at the same time competitive labour costs. These centres are most often located in Asia, but also in Central and Eastern European countries, including Poland (Nowocień, 2007; Mielcarek, 2008; Dominiak, 2012a). These changes would not be 
possible without the use of modern technologies, which are essentially responsible for changes in the sphere of services. Particular importance is attributed to the development of information and telecommunication technologies. Thanks to the Internet, the geographical space permeates with cyberspace (Ilnicki, 2006; Retkiewicz, 2008). The development of the Internet, according to many, not only did not translate into a crisis in geography, but initiated geography of the Internet (Castells, 2003, 2007). The Internet is only seemingly non-location-based and non-spatial (Ilnicki, Janc, 2008; Ilnicki, 2014). In this context, it is worth paying attention to the impact of the Internet and the entire ICT sector on service activity. It caused the transfer of some services to cyberspace and the development of new forms of service provision, distribution and forms of contact with the client. It is responsible for an important aspect of organisational changes in the sphere of services, consisting in the development of new forms of providing traditional services with the use of computer techniques and the Internet (electronic services). Electronic services treated as a new form of providing traditional services or completely new services constitute an important branch of modern geography of services. It is the development of electronic services (e.g. electronic administration, distance education or e-commerce) that revolutionised the sphere of services at the beginning of the 21 st century. In this area, there are papers analysing changes taking place in traditional service activities, e.g. in administration, trade, education, banking, and even medicine due to the use of various types of devices (especially computer devices) and the Internet. Numerous studies are devoted to the functioning of electronic administration, e.g. M. Kaczmarek-Śliwińska (2004), I. Jaros (2005), W. Michalski (2006), R. Perdał (2008; 2011), A. Minkowski, P. Motek, R. Perdał (2009), J. Drobiazgiewicz (2010), T. Taraszkiewicz (2010), and electronic banking - e.g. M. Szcześ, S. Jakubiec (2002), M. Polasik (2007), J. Weltrowska (2008, 2009). Dynamically developing electronic commerce is also gaining more interest, e.g. B. Księżopolski, Z. Kotulski (2004).

In addition to the research trends mentioned above, geography of services is also concerned with issues related to the differences in the level of development of the services sector, structural changes in the services sector, servicisation and the role that services play in the socio-economic development at various spatial scales (national, regional, and local). These issues are the themes of studies of, among others, S.M. Szukalski (2004), J. Dominiak (2004), K. Kłosiński (2006), M. Wodnicka (2009), G. Węgrzyn (2009), I. Rudawska (2009), I. Lichniak (2010). At the same time, it should be pointed out that among the studies in the field of geography of services, the static over dynamic approach is definitely predominant (Ilnicki, 2014), which is related to the changes taking place in the classifications of economic activity. The change of Polish classification of economic activity PKD 2004 to PKD 2007 (forced by changes of the NACE of the EU), led to the lack of comparability and difficulty in conducting analysis of the structural changes of the services sector and dynamic outlines in the time series covering the period before 2009.

\section{PERSPECTIVES AND CHALLENGES FOR THE DEVELOPMENT OF GEOGRAPHY OF SERVICES}

Further development and evolution of geography of services will probably be associated with future changes in the sphere of services. One of the most important challenges seems to be the process of servicisation understood not only as the increase in the 
importance of the third sector (tertiarisation process), but also - and perhaps above all - the process of increasing the importance of service functions, also in the production activity. The growing importance of services in production processes and the links between the production and service sectors leads to the interpenetration of both of these activities (Wyszkowska-Kuna, 2016). According to the theory of Giarini, services cease to be an economic sector, and they are becoming functions that have dominated many production activities at every stage. The intensification of the penetration of material and service products has led to an increased blurring of boundaries between the sphere of services and the sphere of production (the concept of the extended product of Levitt). More and more often we are dealing with an extended product created as a result of continuous enrichment of the offered product with the so-called accompanying services, which over time become an integral part of the product. Production companies do not sell only material goods anymore, but instead offer packages with individualised design, service, etc. There is no unambiguous boundary between companies producing goods and providing services. Many service companies operate on the principle of production companies, and as a result of their activities a standardised, mass service is created. Services have begun to be "produced" like material goods. There is even talk of a process of industrialisation of services ${ }^{1}$ (Szukalski, 2009). On the other hand, production companies are transformed into services due to commissioning the production process itself to subcontractors, while they specialise in design, marketing (e.g. Apple). It is becoming increasingly difficult to clearly assign a company to the sector. Work in production companies is not limited to pure production activities, but more and more employees are involved in service activities such as management, design, finance, marketing. In this context, it seems important to use a functional approach in the analyses of the differences in the level of service development and their types, taking into account the entire sphere of service activity, including the one implemented in the production sectors.

The integrated approach should also cover various scientific fields dealing with issues related to the sphere of services. Increasingly attention is paid to the "appropriation" of the subject of services by technical sciences, especially those related to the ICT sector (Rogoziński, Gnusowski, 2017). It seems, however, that it can be perceived not only in the context of a threat, but also an opportunity offered by such integration. It gives the opportunity to use modern techniques in analyses related to the distribution of service facilities, access to services, or research on the extent of their impact.

It also seems that the trend connected with the development of research on modern knowledge-based services, and in particular their relation to the development of modern economy, will continue. Networking of the economy, the importance of which is emphasised in the context of increasing the level of innovativeness of economies, will result in an increase in the demand for various analyses of links between the sphere of services related to the innovation environment (universities, R\&D sector, institutions responsible for innovation transfer) and business entities implementing innovations.

\section{SUMMARY}

An overview of Polish studies devoted to service activities allows us to formulate the following features of its achievements. In structural terms, one can notice, inter alia, an

1 "The industrialization of services is understood as providing services that take on a massive, standardised character based on the industrial technology of their provision" (Szukalski, 2009: 51). 
increase in interest in modern services based on knowledge; dominance of studies in the field of broadly understood commercial services and a relatively smaller achievements in the field of public services. Trends in services are directly or indirectly related to technological progress, hence they are often referred to in terms of service innovation. It is particularly true of organisational changes (the phenomena of outsourcing and offshoring) and changes in the distribution of services and contact with the client (electronic services), which are the result of the progress in the field of modern information and communication technologies. The main directions of changes in research trends in Polish geography of services in the analysed period are and will be associated with processes occurring in the socio-economic reality.

\section{Reference}

Bajerski, A. (2008). Sieciowe powiązania kadrowe ośrodków akademickich w Polsce [Network connections of academic centers in Poland]. Przegląd Geograficzny, 80(2), 289-300.

Brezdeń, P., Spallek, W. (2009). Zróżnicowanie przestrzenne sieci bankowej w woj. dolnośląskim [Spatial Diversity of Bank Network in Dolnośląskie Voivodeship]. PrzedsiębiorczośćEdukacja [Entrepreneurship-Education], 5, 266-280.

Castells, M. (2003). Galaktyka Internetu [Internet galaxy]. Poznań: Dom Wydawniczy Rebis.

Castells, M. (2007). Społeczeństwo sieci [Network society]. Warszawa: Wydawnictwo Naukowe PWN.

Chojnicki, Z. (1991). Podstawowe problemy metodologiczne rozwoju polskiej geografii [Basic methodological problems of the development of Polish geography]. Poznań: Wydawnictwo Uniwersytetu Adama Mickiewicza.

Ciok, S., Ilnicki, D. (2011). Handel detaliczny w przestrzeni dużego miasta na przykładzie Wrocławia [Retail in the space of a large city on the example of Wrocław]. In: K. Marciniak, K. Sikora, D. Sokołowski (ed.). Koncepcje i problemy badawcze geografii [Concepts and research problems of geography]. Bydgoszcz: Wyższa Szkoła Gospodarki.

Dominiak, J. (2004). Otoczenie biznesu jako czynnik rozwoju społeczno-gospodarczego [Business environment as a factor of socio-economic development]. Przeglad Geograficzny, 76(2), 209-234.

Dominiak, J. (2006). Struktura przestrzenna komercyjnych usług dla biznesu w aglomeracji poznańskiej [Spatial structure of commercial services for business in the Poznań agglomeration]. In: J. Słodczyk, R. Klimek (ed.). Przemiany przestrzeni miast i stref podmiejskich [Changes in the space of cities and suburban zone]. Opole: Uniwersytet Opolski, 53-62.

Dominiak, J. (2008a). Aspekty regionalne rozwoju usług dla biznesu w Polsce [Regional aspects of the development of business services in Poland]. In: J. Dominiak (ed.). Przemiany w sferze usług $w$ Polsce [Transformations in the sphere of services in Poland]. Poznań: Bogucki Wydawnictwo Naukowe, 77-92.

Dominiak, J. (2008b). Zmiany struktury usług dla biznesu w aglomeracji poznańskiej w latach 1995-2005 [Changes in the structure of business services in the Poznań agglomeration in 1995-2005]. In: J. Słodczyk, E. Szafranek (ed.). Mechanizmy i uwarunkowania konkurencyjności miast [Mechanisms and determinants of cities' competitiveness]. Opole: Wydawnictwo Uniwersytetu Opolskiego, 179-189.

Dominiak, J. (2012a). Nowe formy organizacji działalności usługowej i ich rola w rozwoju gospodarczym Poznania na przykładzie Centrów Usług Wspólnych [New forms of organisation of service activities and their role in the economic development of Poznan based on the example of Shared Service Centers]. Biuletyn Instytutu Geografii Społeczno-Ekonomicznej i Gospodarki Przestrzennej UAM. Seria Rozwój Regionalny i Polityka Regionalna [Bulletin of the Institute of Socio-Economic Geography and Spatial Management of the Adam Mickiewicz University. Regional Development and Regional Policy Series].

Dominiak, J. (2012b). Poziom i dynamika rozwoju otoczenia biznesu w Polsce. Studium porównawcze największych miast $w$ Polsce [The level and dynamics of business environment develop- 
ment in Poland. A comparative study of the largest cities in Poland]. Opole: Wydawnictwo Uniwersytetu Opolskiego.

Dominiak, J. (2013). Wpływ usług otoczenia biznesu na rozwój społeczno-gospodarczy regionów $\mathrm{w}$ Polsce [The role of the business environment in regional development in Poland]. Prace Komisji Geografii Przemysłu Polskiego Towarzystwa Geograficznego [Studies of the Industrial Geography Commission of the Polish Geographical Society], 22.

Dominiak, J. (2017a). Nowoczesne usługi a poziom rozwoju gospodarczego [Modern Services and the Level of Economic Development]. Prace Komisji Geografii Przemysłu Polskiego Towarzystwa Geograficznego [Studies of the Industrial Geography Commission of the Polish Geographical Society], 31(1), 81-96.

Dominiak, J. (2017b). Outsourcing w przedsiębiorstwach aglomeracji wielkopolskiej [Outsourcing in enterprises of the Poznań agglomeration]. Biuletyn Rozwój Regionalny i Polityka Regionalna, 40.

Dominiak, J. (2018). Modern services: terminological considerations and the characteristic features of their role in socio-economic development. Quaestiones Geographicae, 37(2), 17-26.

Drobiazgiewicz, J. (2010). E-administracja w Polsce [E-administration in Poland]. Zeszyty Naukowe Uniwersytetu Szczecińskiego. Ekonomiczne Problemy Usług [Scientific Papers of the University of Szczecin. Economic Problems of Services], 355-360.

Dzieciuchowicz, J. (2009a). Indywidualność usług dla producentów i biznesu [Individuality of services for producers and business]. In: J. Dzieciuchowicz (ed.). Usługi dla producentów i biznesu w przestrzeni wielkomiejskiej. Przykład Łodzi [Services for producers and business in urban space. The example of Łódź]. Łódź: Wydawnictwo Uniwersytetu Łódzkiego, 5-17.

Dzieciuchowicz, J. (2009b). Rozwój usług dla producentów i biznesu w Łodzi [Development of services for producers and business in Łódź]. In: J. Dzieciuchowicz (ed.). Usługi dla producentów i biznesu w przestrzeni wielkomiejskiej. Przykład Łodzi [Services for producers and business in urban space. The example of Łódź]. Łódź: Wydawnictwo Uniwersytetu Łódzkiego, 18-31.

Dzieciuchowicz, J., (2009c). Struktura przestrzenna usług dla producentów i biznesu [Spatial structure of services for producers and business]. In: J. Dzieciuchowicz (ed.). Usługi dla producentów i biznesu w przestrzeni wielkomiejskiej. Przykład Łodzi [Services for producers and business in urban space. The example of Łódź]. Łódź: Wydawnictwo Uniwersytetu Łódzkiego, 32-49.

Dzieciuchowicz, J. (2009d). Typologia przestrzenna usług dla producentów i biznesu [Spatial typology of services for producers and business]. In: J. Dzieciuchowicz (ed.). Usługi dla producentów i biznesu w przestrzeni wielkomiejskiej. Przykład Łodzi [Services for producers and business in urban space. The example of Łódź]. Łódź: Wydawnictwo Uniwersytetu, 50-60.

Dzieciuchowicz, J. (2009e). Rozwój i funkcjonowanie usług dla producentów i biznesu w przestrzeni wielkomiejskiej Łodzi - ogólne prawidłowości [Development and functioning of services for producers and businesses in the urban space of Łódź - general regularities]. In: J. Dzieciuchowicz (ed.). Usługi dla producentów i biznesu w przestrzeni wielkomiejskiej. Przykład Łodzi [Services for producers and business in urban space. The example of Łódź]. Łódź: Wydawnictwo Uniwersytetu Łódzkiego, 184-190.

Dzieciuchowicz, J. (2009f) (ed.). Usługi dla producentów i biznesu w przestrzeni wielkomiejskiej. Przykład Łodzi [Services for producers and business in urban space. The example of Łódź]. Łódź: Wydawnictwo Uniwersytetu Łódzkiego.

Dzieciuchowicz, J. (2012a). Nowa geografia handlu [New geography of trade]. Acta Universitatis Lodziensis. Folia Geographica Socio-Oeconomica, 12, 37-53.

Dzieciuchowicz, J. (2012b). Wielkie centrum handlowe w przestrzeni miejskiej i pozamiejskiej. Manufaktura $w$ Łodzi i Ptak w Rzgowie [A shopping mall in urban and extra-urban space. 'Manufaktura' in Łódź and 'Ptak' in Rzgów]. Łódź: Wydawnictwo Uniwersytetu Łódzkiego.

Gaczek, W.M. (2006). Poznań jako ośrodek akademicki [Poznań as an academic center]. In: W.M. Gaczek, M. Kaczmarek, D. Marcinowicz (ed.). Poznański ośrodek akademicki. Próba określenia wpływu studentów na rozwój miasta [Poznań academic center. An attempt to determine the influence of students on the development of the city]. Poznań: Bogucki Wydawnictwo Naukowe. 
Ilnicki, D. (2001). Bankomat jako usługa nowa [ATM as a new service]. In: I. Łęcka (ed.). Geografia różnorodności - różnorodność w geografii [Geography of diversity - diversity in geography]. Warszawa: Instytut Krajów Rozwijających się, Wydział Geografii i Studiów Regionalnych, Uniwersytet Warszawski, 45-51.

Ilnicki, D. (2003). Wyznaczniki współczesnych przekształceń w sferze usług nowych a poziom rozwoju gospodarczego [The determinants of contemporary transformations in the sphere of new services and the level of economic development]. W: H. Rogacki (ed.). Problemy interpretacji wyników metod badawczych stosowanych w geografii społeczno-ekonomicznej i gospodarce przestrzennej [Problems of interpretation of the results of research methods used in socio-economic geography and spatial management]. Poznań: Bogucki Wydawnictwo Naukowe, 295-309.

Ilnicki, D. (2006). Usługa bankomatowa jako nowe zjawisko w starej przestrzeni [ATM service as a new phenomenon in the old space]. In: I. Jażdżewska (ed.). Nowe przestrzenie $w$ miastach. Ich organizacja i funkcje. XIX Konwersatorium Wiedzy o Mieście [New spaces in the cities. Their organisation and functions. The 19th Conversatorium of Knowledge about the City]. Łódź: Uniwersytet Łódzki, 289-304.

Ilnicki, D. (2008). Przestrzenne aspekty funkcjonowania wyższych uczelni w Polsce [Spatial aspects of functioning of universities in Poland]. In: T. Markowski, D. Drzazga (ed.). Rola wyższych uczelni w rozwoju społeczno-gospodarczym i przestrzennym miast [The role of universities in the social and economic development of cities and towns]. Studia Komitetu Przestrzennego Zagospodarowania Kraju Polskiej Akademii Nauk, 121, 33-44.

Ilnicki, D. (2009). Przestrzenne zróżnicowanie poziomu rozwoju usług w Polsce. Teoretyczne i praktyczne uwarunkowania badań [Spatial differentiation of the level of service development in Poland. Theoretical and practical determinants of research]. Rozprawy Naukowe Instytutu Geografii i Rozwoju Regionalnego Uniwersytetu Wrocławskiego, 11.

Ilnicki, D. (2014). Usługi w polskiej literaturze przedmiotu. Ujęcie chronologiczno-tematyczne [Services in Polish literature on the subject. Chronological and thematic approach]. SpaceSociety-Economy, 13, 203-246.

Ilnicki, D., Janc K. (2008). Węzłowość i przestrzeń przepływów Internetu. Ujęcie globalne i lokalne. Geopolis - Elektroniczne Czasopismo Geograficzne, 1, 7-26

Jakubowicz, E. (1993). Podstawy metodologiczne geografii usług. Wrocław: Wydawnictwo Uniwersytetu Wrocławskiego.

Jakubowicz, E. (2000). Rola usług „nowych” w przekształceniach systemu miast regionu dolnośląskiego [The role of "new" services in transformations of the Dolnośląskie Voivodeship's urban system]. In: J. Słodczyk (ed.). Społeczne, gospodarcze i przestrzenne przeobrażenia miast [Social, economic and spatial transformations of cities]. Opole: Uniwersytet Opolski, 177-186.

Janc, A. (2001). Nowe usługi na tle wybranych problemów organizacji [New services against selected organisational problems]. Poznań: Biblioteka Menedżera i Bankowca.

Jaros, I. (2005). E-government. Administracja publiczna w społeczeństwie informacyjnym - wprowadzenie teoretyczne [E-government. Public administration in the information society - a theoretical introduction]. Zeszyty Naukowe Politechniki Śląskiej. Organizacja i Zarządzanie, 31, 25-35.

Kaczmarek, T. (2014). Rozwój, struktura przestrzenna i funkcje centrów handlowych w Polsce [Development, spatial structure and functions of shopping centres in Poland]. SpaceSociety-Economy, 13, 247-267.

Kaczmarek, T., Kaczmarek, U. (2006). Stara i nowa przestrzeń handlowa Poznania [Old and new commercial space of Poznan]. In: I. Jażdżewska (ed.). Nowe przestrzenie w miastach. Ich organizacja i funkcje. XIX Konwersatorium Wiedzy o Mieście [New spaces in cities. Their organisation and functions, The 19th Seminar of Knowledge about the City]. Łódź: Uniwersytet Łódzki, 221-230.

Kaczmarek-Śliwińska, M. (2004) (2018, 10 May). Stan e-government w Polsce [The state of e-government in Poland]. E-mentor, 5(7). Obtained from http://www.e-mentor.edu.pl/artykul/ index/numer/7/id/100

Kłosiński, K. (2006). Sektor usług w Polsce i krajach Unii Europejskiej w latach 1995-2003 [Service sector in Poland and European Union countries in the years 1995-2003]. Handel Wewnętrzny, 3, 57-61. 
Kłosowski, F. (2006a). Sektor usług w gospodarce regionu tradycyjnego w warunkach transformacji i restrukturyzacji. Przykład konurbacji katowickiej [The service sector in the economy of the traditional region in the conditions of transformation and restructuring. An example of the Katowice conurbation]. Katowice: Wydawnictwo Uniwersytetu Śląskiego.

Kłosowski, F. (2006b). Tendencje zmian w sektorze usług konurbacji katowickiej w latach 1991-2002 [Trends of changes in the Katowice Conurbation Service sector in 1991-2002]. In: J. Słodczyk, E. Szafranek (red.). Kierunki przekształceń struktury gospodarczej i społeczno-demograficznej miast [Directions of transformation of the economic and socio-demographic structure of cities]. Opole: Uniwersytet Opolski, 85-98.

Księżopolski, B., Kotulski, Z. (2004). Zagrożenia procesów komunikacyjnych e-commerce oraz sposoby przeciwdziałania [Threats of e-commerce communication processes and counteracting methods]. In: J. Kisielnicki (ed.). Informatyka narzędziem współczesnego zarządzania [Information technology as a tool of modern management]. Warszawa: Polsko-Japońska Wyższa Szkoła Technik Komputerowych.

Liberska, B. (2008). Globalizacja a offshoring usług sektora IT [Globalisation and offshoring of the IT services]. In: A. Szymaniak (ed.). Globalizacja usług, outsourcing, offshoring i shared services centres [Globalisation of services, outsourcing, offshoring and shared services centres]. Warszawa: Wydawnictwo Akademickie i Profesjonalne, 237-254.

Lichniak, I. (2010). Ku gospodarce usług [Towards the service economy]. In: L. Lichniak (ed.). Serwicyzacja polskiej gospodarki [Servicing of the Polish economy]. Warszawa: Oficyna Wydawnicza Szkoły Głównej Handlowej, 11-24.

Masłowski, A. (2008). Globalizacja rynku usług [Globalisation of the services market]. In: A. Szymaniak (ed.). Globalizacja usług. Outsourcing, offshoring i shared services centers [Globalisation of services. Outsourcing, offshoring and shared services centres]. Poznań: Wydawnictwa Akademickie i Profesjonalne, 85-100.

Męczyński, M. (2006). Przestrzenne zróżnicowanie i wykorzystania technologii informacyjno-komunikacyjnych w przedsiębiorstwach przemysłowych w Polsce [Spatial Differentiation of the Level of Innovation of Regional Economy of Lower Silesian Voivodeship]. Prace Komisji Geografii Przemysłu Polskiego Towarzystwa Geograficznego [Studies of the Industrial Geography Commission of the Polish Geographical Society], 9, 116-129.

Micek, G. (2006). Mechanizmy koncentracji przestrzennej firm informatycznych w Polsce [Mechanisms of spatial concentration of IT companies in Poland]. In: Z. Szyjewski, J. Nowak, J. Grabara (ed.). Strategie informatyzacji [Computerisation strategies]. Katowice: Polskie Towarzystwo Informatyczne - Oddział Górnośląski, 87-96.

Micek, G. (2008). Rozwój usług informatycznych w Polsce w ujęciu przestrzennym [Development of IT services in Poland in spatial terms]. In: J. Dominiak (ed.). Przemiany $w$ sferze usług $w$ Polsce [Transformations in the sphere of services in Poland]. Poznań: Bogucki Wydawnictwo Naukowe, 93-110.

Michalski, W. (2006). Ocena zapotrzebowania społecznego na elektroniczne usługi świadczone przez urzędy administracji publicznej w Polsce [Assessment of public demand for electronic services provided by public administration offices in Poland]. Telekomunikacja i Techniki Informacyjne, 1-2.

Mielcarek, P. (2008). Uwarunkowania zastosowania outsourcingu w działalności gospodarczej [Conditions for the use of outsourcing in business]. In: J. Dominiak (ed.). Przemiany w sferze usług $w$ Polsce [Transformations in the sphere of services in Poland]. Poznań: Bogucki Wydawnictwo Naukowe, 111-128.

Minkowski, A., Motek, P., Perdał, R. (2009). Poziom zaawansowania wielkopolskich urzędów gmin w zakresie informatyzacji i rozwoju elektronicznych usług publicznych [The level of advancement of the Wielkopolska gmina offices in the field of computerisation and development of electronic public services]. Poznań: Wydawnictwo M-Druk.

Naisbitt, J. (1997). Megatrends Asia. London: Nicholas Brealey,

Nowocień, J. (2007). Outsourcing w działalności Capgemini na przykładzie centrum BPO i ITO w Polsce [Outsourcing in the Capgemini business based on the example of the BPO and ITO centres in Poland]. In: A. Szymaniak (ed.). Globalizacja usług. Outsourcing, offshoring i shared services centers [Globalisation of services, outsourcing, offshoring and shared services centres]. Poznań: Wydawnictwo Naukowe Uniwersytetu Adama Mickiewicza. 
Nowosielska, E. (1994). Główne tendencje rozwojowe ostatniego dwudziestolecia i aktualne problemy badawcze [Main development trends of the last twenty years and current research problems]. Zeszyty Instytut Geografii i Przestrzennego Zagospodarowania Polskiej Akademii Nauk, 22.

Perdał, R. (2008). Poziom rozwoju usług elektronicznej administracji w gminach województwa wielkopolskiego [The level of development of electronic administration services in the gminas of Wielkopolskie Voivodeship]. In: J. Dominiak (ed.). Przemiany w sferze usług w Polsce [Transformations on the sphere of services in Poland]. Poznań: Bogucki Wydawnictwo Naukowe, 29-64.

Perdał, R. (2011). Regionalne zróżnicowanie poziomu dostępu i wykorzystania internetu w Polsce [Regional diversification of the level of access and use of the Internet in Poland]. Biuletyn Komisji Przestrzennego Zagospodarowania Kraju Polskiej Akademii Nauk, 248, 85-105.

Polarczyk, K. (1970). Miary zasięgu oddziaływania zakładów usługowych. Sprawozdania PTPN za II półrocze IG PAN [Measures of the range of impact of service plants. PTPN reports for the second half of IG PAN], 2, 322-326.

Polarczyk, K. (1971). Wynik pracy podstawą definicji i klasyfikacji usług oraz sfery usług [The result of the work as the basis for the definition and classification of services and the sphere of services]. Ruch Prawniczy, Ekonomiczny i Socjologiczny [Legal, Economic and Sociological Movement], 1, 189-203.

Polarczyk, K. (1976a). Struktura przestrzenna usług w mieście Poznaniu [Spatial structure of services in the city of Poznań]. Dokumentacja Geograficzna [Geographical Documentation] 1, 93-95.

Polarczyk, K. (1976b). The Distribution of Service Centers within Large Urban Areas. A Market Accessibility Model. Geographia Polonica, 33(2), 143-155.

Polarczyk, K. (1979). Kierunki badań wewnątrzmiejskiej struktury usług [Directions of research of urban structure of services]. In: Z. Chojnicki (ed.). Struktura i funkcje układów przestrzenno-ekonomicznych [Structure and functions of the spatio-economic arrangements]. Poznań: Wydawnictwo Uniwersytetu Adama Mickiewicza, 81-95.

Polasik, M. (2007). Bankowość elektroniczna. Istota - stan - perspektywy [Electronic banking. Essence - state - perspectives]. Warszawa: CeDeWu.

Retkiewicz, W. (2008). Wybrane koncepcje cyberprzestrzeni w geografii [Chosen concepts of cyberspace in geography]. In: W. Maik, K. Rembowska, A. Suliborski (ed.). Terytorium, region, miejsce - czas i przestrzeń w geografii. Podstawowe idee i koncepcje w geografii [Territory, region, place - time and space in geography. Basic ideas and concepts in geography]. Bydgoszcz: Wyższa Szkoła Gospodarki, 115-128.

Retkiewicz, W. (2014a). Przestrzenna natura cyberprzestrzeni [The spatial nature of cyberspace]. In: Z. Rykiel, J. Kinal (ed.). Wirtualność jako realność [Virtuality as a reality]. Rzeszów: Wydawnictwo Uniwersytetu Rzeszowskiego.

Retkiewicz, W. (2014b). Internet jako nowy przedmiot w badaniach geograficznych [Internet as a new subject in geographic surveys]. In: W. Maik, K. Rembowska, A. Suliborski (ed.). Dorobek polskiej geografii po konferencji w Radzynie. Ocena krytyczna [Achievements of Polish geography after the conference in Radzyń. Critical rating]. Łódź: Wydawnictwo Uniwersytetu Łódzkiego, 155-162.

Rogoziński, K., Gnusowski, M. (2017). Powiernictwo - interdyscyplinarnie ujęty przyczynek do nowej teorii usług [Trust - an interdisciplinary included contribution to the new theory of services]. Współczesne problemy ekonomiczne [Contemporary economic problems], 2(15), $17-31$.

Rudawska, I. (ed.) (2009). Usługi w gospodarce rynkowej [Services in a market economy]. Warszawa: Polskie Wydawnictwo Ekonomiczne.

Skórska, A. (2012). Wiedzochłonne usługi biznesowe w Polsce i innych krajach Unii Europejskiej [Knowledge-intensive business services in Poland and other European Union countries]. Katowice: Wydawnictwo Uniwersytetu Ekonomicznego w Katowicach.

Skórska, A. (2015). Przestrzenne zróżnicowanie rozwoju przemysłu i usług high-tech w krajach Europy Środkowo-Wschodniej [Spatial Diversity of High-Tech Industry and KnowledgeIntensive Services Development in Central-Eastern Europe]. Prace Komisji Geografii 
Przemysłu Polskiego Towarzystwa Geograficznego [Studies of the Industrial Geography Commission of the Polish Geographical Society]. 29(2), 53-65.

Skórska, A. (2016). Regionalne zróżnicowanie innowacyjności sektora usług w Polsce [Regional diversification of innovativeness of the services sector in Poland]. Studia Ekonomiczne. Zeszyty Naukowe Uniwersytetu Ekonomicznego w Katowicach [Economic Studies. Zeszyty Naukowe of the University of Economics in Katowice], 291, 127-138.

Sobczyński, M., Słowik, A., (2000). Przestrzenne zróżnicowanie innowacyjności w sferze nieprodukcyjnej w województwie łódzkim [Spatial diversification of innovativeness in the non-productive sphere in the Łódzkie Voivodeship]. In: S. Ciok, D. Ilnicki (ed.). Przekształcenia regionalnych struktur funkcjonalno-przestrzennych [Transformations of regional functional and spatial structures]. Wrocław: Uniwersytet Wrocławski, 375-387.

Strożek, P., Jewczak, M. (2016). Rozwój sektora ICT w Polsce - ocena międzyregionalna [The development of the ICT sector in Poland - interregional evaluation]. Zeszyty Naukowe Uniwersytet Ekonomiczny w Krakowie, 9(957), 101-117.

Stryjakiewicz, T. (2009). Lokalizacja firm i zachowania przestrzenne pracowników sektora informatycznego (na przykładzie poznańskiego obszaru metropolitalnego) [Location of firms and spatial behaviour of employees of the IT sector (the case of the Poznań metropolitan area)). Prace Komisji Geografii Przemysłu Polskiego Towarzystwa Geograficznego [Studies of the Industrial Geography Commission of the Polish Geographical Society], 13, 21-33.

Szcześ, M., Jakubiec, S. (2002). Elektroniczne usługi finansowe - charakterystyka rynku, wyzwania $i$ inicjatywy regulacyjne [Electronic financial services - market characteristics, challenges and regulatory initiatives]. Warszawa: Narodowy Bank Ppolski.

Szukalski, S.M. (2004). Serwicyzacja gospodarki i industrializacja usług. Handel Wewnętrzny [Servicisation of the economy and industrialisation of services]. Internal Trade, 4-5.

Szukalski S.M. (2009). Determinanty i kierunki rozwoju sektora usług w Polsce w perspektywie 2020 r. Handel Wewnętrzny 5, 15-24.

Taraszkiewicz, T. (2010). E-usługi w administracji publicznej na przykładzie samorządowej elektronicznej platformy informacyjnej w Gdańsku [E-services in public administration based on the example of the local electronic information platform in Gdańsk]. Zeszyty Naukowe Uniwersytetu Szczecińskiego. Ekonomiczne Problemy Usług [Scientific Papers of the University of Szczecin. Economic Problems of Services], 58, 417-425.

Weltrowska, J. (2003). Rozwój przestrzenny systemu bankowego w Polsce w latach 1989- 2002 [Spatial development of the banking system in Poland in 1989-2002]. Poznań: Bogucki Wydawnictwo Naukowe.

Weltrowska, J. (2007). Regionalne zróżnicowanie poziomu rozwoju bankowości w Polsce [Regional diversification of the level of banking development in Poland]. Przekształcenia regionalnych struktur funkcjonalno-przestrzennych [Transformations of the regional functional and spatial structures], 9, 339-349.

Weltrowska, J. (2008). Rozwój usług bankowości elektronicznej w Polsce [Development of electronic banking services in Poland]. In: J. Dominiak (ed.). Przemiany w sferze usług $w$ Polsce [Transformations in the sphere of services in Poland]. Poznań: Bogucki Wydawnictwo Naukowe, 65-77.

Weltrowska, J. (2009). Rozwój usług bankowości elektronicznej w Polsce [Development of electronic banking services in Poland]. In: J. Dominiak (ed.). Przemiany w sferze usług w Polsce [Transformations in the sphere of services in Poland]. Poznań: Bogucki Wydawnictwo Naukowe, 65-76.

Werwicki, A. (1998). Zmiana paradygmatu geografii usług [Changes in the paradigm of the geography of services]. Przegląd Geograficzny, 70(3-4), 249-267.

Węgrzyn, G. (2009). Rola sektora usług we współczesnej ekspansji gospodarczej [The role of the service sector in contemporary economic expansion]. In: K. Piech, B. Kryk (ed.). Innowacyjność $w$ skali makro i mikro [Innovation on the macro and micro scale]. Warszawa: Instytut Wiedzy i Innowacji.

Węgrzyn, G. (2013). Sektor usług w gospodarce opartej na wiedzy - studium komparatystyczne [Services sector in a knowledge-based economy - a comparative study. Oeconomia Copernicana, 1. 
Więcław-Michniewska, J. (2006). Nowe przestrzenie handlowe w aspekcie realizacji zadań samorządu terytorialnego [New commercial spaces in the aspect of the implementation of tasks of local self-government]. In: I. Jażdżewska (ed.). Nowe przestrzenie $w$ miastach. Ich organizacja i funkcje. XIX Konwersatorium Wiedzy o Mieście [New spaces in the cities. Their organisation and functions. The $19^{\text {th }}$ Seminar of Knowledge about the City]. Łódź: Uniwersytet Łódzki, 277-286.

Wilk, W. (2005). Miejsce miast w sieciach handlowych - przykład Polski [Place of cities in shopping chains - an example of Poland]. Prace i Studia Geograficzne, 35, 129-153.

Wilk, W. (2012). Obecność handlu dyskontowego a poziom rozwoju regionów w państwach Grupy Wyszehradzkiej [The presence of discount trade and the level of development of regions in the countries of the Visegrad Group]. Rozprawy Naukowe Instytutu Geografii i Rozwoju Regionalnego Uniwersytetu Wrocławskiego [Scientific Dissertations of the Institute of Geography and Regional Development of the University of Wrocław], 28, 81-92.

Wilk, W. (2013). Koncepcja sieci a geografia zorganizowanego handlu detalicznego w Polsce [The concept of networks and the geography of organised retail trade in Poland]. Warszawa: Wydawnictwo Uniwersytetu Warszawskiego.

Wiśniewski, E. (2008). Wpływ szkolnictwa wyższego na rozwój społeczno-gospodarczy Kołobrzegu [Impact of higher education on the socio-economic development of Kołobrzeg]. Studia Komisji Przestrzennego Zagospodarowania Kraju Polskiej Akademii Nauk, 121, 126131.

Wodnicka, M. (2009). Rola usług w rozwoju gospodarczym Polski [The role of services in the economic development of Poland]. Zeszyty Naukowe Małopolskiej Wyższej Szkoły Ekonomicznej w Tarnowie [Zeszyty Naukowe of the Małopolska School of Economics in Tarnów], 2(13).

Wolaniuk, A. (2006). Szkolnictwo wyższe [Higher education]. In: J. Dzieciuchowicz (ed.). Usługi nierynkowe w przestrzeni miejskiej Łodzi [Non-market services in the urban space of Łódż]. Łódź: Wydawnictwo Uniwersytetu Łódzkiego, 86-107.

Wolaniuk, A. (2008). Rola i miejsce wyższych uczelni w organizacji przestrzeni miasta [The role and place of universities in the organisation of the city space]. Studia Komisji Przestrzennego Zagospodarowania Kraju Polskiej Akademii Nauk, 121, 45-60.

Wyszkowska-Kuna J. (2016). Usługi biznesowe oparte na wiedzy. Wpływ na konkurencyjność gospodarki na przykładzie wybranych krajów Unii Europejskiej [Knowledge-based business services. Impact on the competitiveness of the economy on the example of selected countries of the European Union]. Łódź: Wydawnictwo Uniwersytetu Łódzkiego.

Zięba, M. (2015). Sektor usług wiedzochłonnych oraz jego dynamika i struktura zatrudnienia w krajach Unii Europejskiej [Knowledge-intensive services sector and its dynamics and employment structure in the European Union countries]. Ekonomia, 40.

Zorska, A. (2007). Outsourcing i przenoszenie usług na świecie. Wnioski dla Polski [Outsourcing and relocation of services in the world. Applications for Poland]. Gospodarka Narodowa [National Economy], 1-2.

Zorska, A. (2008). Outsourcing i przenoszenie usług w dobie globalizacji oraz informatyzacji [Outsourcing and relocation of services in the era of globalisation and computerisation]. In: A. Szymaniak (ed.). Globalizacja usług outsourcing, offshoring i shared services centres [Globalisation of outsourcing, offshoring and shared services centres]. Warszawa: Wydawnictwo Akademickie i Profesjonalne.

Joanna Dominiak, Ph.D., assistant professor in the Department of the Regional Analysis in the Institute of Socio-Economic Geography and Spatial Management of Adam Mickiewicz University in Poznań. Her academic interests revolve around the role of innovation in the development of the knowledge-based economy, the impact of the business environment on the development of regions and changes in the structure of services.

Address:

Adam Mickiewicz University

Institute of Socio-Economic Geography and Spatial Management

ul. Dzięgielowa 27, 61-680 Poznań, Poland

e-mail:dominiak@amu.edu.pl 